\title{
THE EFFECTS OF SOIL MANAGEMENT PRACTICES ON SOIL ORGANIC MATTER CHANGES WITHIN A PRODUCTIVE VINEYARD IN THE NITRA VITICULTURE AREA (SLOVAKIA)
}

\author{
VLADIMÍR ŠIMANSKÝ*, NORA POLLÁKOVÁ
}

Slovak University of Agriculture in Nitra, Slovak Republic

\begin{abstract}
ŠIMANSKÝ, V. - POLLÁKOVÁ, N.: The effects of soil management practices on soil organic matter changes within a productive vineyard in the Nitra viticulture area (Slovakia). Agriculture (Pol'nohospodárstvo), vol. 62, 2016, no. 1, p. $1-9$.
\end{abstract}

Since understanding soil organic matter (SOM) content and quality is very important, in the present study we evaluated parameters of SOM including: carbon lability $\left(\mathrm{L}_{\mathrm{C}}\right)$, lability index (LI), carbon pool index (CPI) and carbon management index (CMI) in the soil as well as in the water-stable aggregates (WSA) under different soil management practices in a commercial vineyard (established on Rendzic Leptosol in the Nitra viticulture area, Slovakia). Soil samples were taken in spring during the years 2008-2015 from the following treatments: G (grass, control), T (tillage and intensive cultivation), T+FYM (tillage + farmyard manure), G+NPK3 (grass $+3^{\text {rd }}$ intensity of fertilisation for vineyards), and $\mathrm{G}+\mathrm{NPK} 1$ (grass $+1^{\text {st }}$ intensity of fertilisation for vineyards). The highest LI values in soil were found for the G+NPK3 and T+FYM fertilised treatments and the lowest for the unfertilised intensively tilled treatments. The CPI in the soil increased as follows: $\mathrm{T}<\mathrm{G}+\mathrm{NPK} 3<\mathrm{T}+\mathrm{FYM}<\mathrm{G}+\mathrm{NPK} 1$. The highest accumulation of carbon as well as decomposable organic matter occurred in G+NPK1 compared to other fertilised treatments, while intensive tillage caused a decrease. On average, the values of LI in WSA increased in the sequence $\mathrm{G}+\mathrm{NPK} 1<\mathrm{T}+\mathrm{FYM}<\mathrm{G}+\mathrm{NPK} 3<\mathrm{T}$. Our results showed that the greatest SOM vulnerability to degradation was observed in the WSA under T treatment, and the greatest values of CPI in WSA were detected as a result of fertiliser application in $3^{\text {rd }}$ intensity for vineyards and farmyard manure application.

Key words: index lability, carbon pool index, carbon management index, fertilisation, soil tillage, vineyard

SOM represents a polyfunctional, uneven-aged, multicomponent continuum of destroyed plant residues, root exudates, microbial biomass, biomolecules, and humic substances. It has lifetimes varying from several hours or days through to millennia (Schepaschenko et al. 2013; Semenov et al. 2013). SOM content in the soils is influenced by several factors, such as climate, clay content and mineralogy and soil management techniques etc. (Stevenson 1982; Lugato \& Berti 2008). Organic carbon content in the soil (SOC) is one of the qualitative parameters of the soil humus regime and long has been recognized as a key component of soil quality
(Reeves 1997). SOC can be divided into labile and recalcitrant fractions based on the relative susceptibility to biological decomposition (McLauchlan \& Hobbie 2004; Belay-Tedla et al. 2009). Labile SOC pools such as water-extractable organic $\mathrm{C}$, hot water-soluble organic $\mathrm{C}$, potassium permanganate oxidizable organic $\mathrm{C}$, and organic $\mathrm{C}$ fractions of different oxidizability are considered to respond to agricultural management more rapidly than total organic C (Blair et al. 1995; Benbi et al. 2012). As such labile fractions of SOM are used as sensitive indicators for soil management and land use induced changes in soil quality (Kolář et al. 2011; Benbi

doc. Ing. Vladimír Šimanský, PhD. (* Corresponding author), Department of Soil Science, FAFR - SUA Nitra, 94976 Nitra, Tr. A. Hlinku 2, Slovak Republic. E-mail: Vladimir.Simansky@uniag.sk doc. Ing. Nora Polláková, PhD., Department of Soil Science, FAFR - SUA Nitra, 94976 Nitra, Tr. A. Hlinku 2, Slovak Republic. E-mail: Nora.Pollakova@uniag.sk 
et al. 2015; Shang et al. 2016). Small changes in total SOM are difficult to detect because of its high background levels and natural soil variability. For this reason Blair et al. (1995) recommended the use of the carbon lability $\left(\mathrm{L}_{\mathrm{C}}\right)$, lability index (LI), carbon pool index (CPI) and carbon management index (CMI) for the determination of smaller changes and changes over a short time period. These parameters have been rather quickly adopted and used for the evaluation of SOM changes (Szombathová 1999; 2010). However, data about $L_{C}, L I, C M I$ and CPI in individual size fractions of water-stable aggregates are very rare.

In this study we evaluated the effect of different soil management practices on $\mathrm{L}_{\mathrm{C}}$, LI, CPI and CMI parameters in (i) the soil and (ii) the water-stable aggregates. Finally, we investigated relationships between these parameters within both the soil and water-stable aggregates.

\section{MATERIAL AND METHODS}

The study was conducted at Dražovce (48²1'6.16"N; 18³'37.33”E), a village located near Nitra city in the west of Slovakia. The area (vineyard) is located under the south-west side of the Tribeč Mountain. In the $11^{\text {th }}$ century, the southern slopes of the Zobor hills were deforested and vineyards were planted. Today the locality is used as a horticulture area and for growing wines. The climate is temperate with a mean annual rainfall of $550 \mathrm{~mm}$ and the mean annual temperature $\geq 10^{\circ} \mathrm{C}$. The soil was classified as Rendzic Leptosol (WRB 2006) with a sandy loam texture developed on limestone and dolomite. Characteristics of the topsoil $(0-30 \mathrm{~cm})$ before the experiment in 2000 are presented in Table 1.

Before vineyard establishment the locality was abandoned. In the year 2000, the vines (Vitis vinifera L. cv. Chardonnay) had been planted and up to the year 2003 the vineyard was intensively cultivated in and between rows of the vine (mechanical removal of weeds). In 2003, a variety of grasses in following ratio Lolium perenne $50 \%+$ Poa pratensis $20 \%$ + Festuca rubra commutata $25 \%$ + Trifolium repens $5 \%$ were sown in and between rows of the vine. In the year 2006, the experimentation of different soil management practices in a productive vineyard was initiated. This experimental design had been previously described by Šimanský \& Polláková (2014). Briefly, the treatments consisted of (1). G: as a control (in the rows and between vines rows, a mixture of the grass were sown), (2). T: tillage (in autumn tilth to a depth of $25 \mathrm{~cm}$ and intensive cultivation between vine rows during the growing season), (3). T+FYM: tillage + farmyard manure (ploughed farmyard manure at a dose of $40 \mathrm{t} / \mathrm{ha}$ in autumn 2005, 2009 and 2012), (4). G+NPK3: doses of NPK fertilisers in $3^{\text {rd }}$ intensity for vineyards, this means $120 \mathrm{~kg} / \mathrm{ha}$ of N, $55 \mathrm{~kg} / \mathrm{ha}$ of P and $195 \mathrm{~kg} / \mathrm{ha}$ of $\mathrm{K} \mathrm{kg} / \mathrm{ha}$ (Fecenko \& Ložek 2000). The dose of nutrients was divided: $2 / 3$ applied into the soil in the spring (bud burst) and $1 / 3$ at flowering. The grass was sown in and between the vine rows. (5). G+NPK1: doses of NPK fertilisers in $1^{\text {st }}$ intensity for vineyards, this means $80 \mathrm{~kg} / \mathrm{ha}$ of N, $35 \mathrm{~kg} / \mathrm{ha}$ of $\mathrm{P}$ and $135 \mathrm{~kg} / \mathrm{ha}$ of K (Fecenko \& Ložek 2000). The dose of nutrients was divided: $1 / 2$ applied into the soil in the spring (bud burst) and 1/2 at flowering. The grass was sown in and between the vine rows.

Sampling was done in the spring throughout the years 2008-2015. Soil samples were collected (0-20 cm layer) from 4 random locations within each treatment of different vineyard soil management practices. Soil samples were then mixed together to form an average sample for each treatment. Samples were air-dried. Then, each of the samples was divided and one half of them were sieved through a $2 \mathrm{~mm}$ sieve for chemical analyses and the second half of samples were used for the determination of water-stable aggregates (WSA).

$\mathrm{T}$ a

Characteristics of a Rendzic Leptosol at NitraDražovce in the year 2000

\begin{tabular}{|l|c|}
\hline Soil properties & Means and standard deviation \\
\hline Rock fragments [\%] & $8 \pm 1.6$ \\
Clay $[\mathrm{g} / \mathrm{kg}]$ & $101 \pm 12$ \\
Silt $[\mathrm{g} / \mathrm{kg}]$ & $330 \pm 18$ \\
Sand $[\mathrm{g} / \mathrm{kg}]$ & $569 \pm 23$ \\
Organic carbon $[\mathrm{g} / \mathrm{kg}]$ & $17.0 \pm 1.6$ \\
Base saturation $[\%]$ & $99.3 \pm 0.01$ \\
$\mathrm{pH}\left(\right.$ in $\left.1 \mathrm{~mol} / \mathrm{dm}^{3} \mathrm{KCl}\right)$ & $7.18 \pm 0.08$ \\
\hline
\end{tabular}


Seven aggregate-size fractions $(>5,5-3,3-2$, $2-1,1-0.5,0.5-0.25$ and $<0.25 \mathrm{~mm})$ were separated by the wet-sieving of the soil through the series of six sieves using the Baksheev method. The method for aggregate separation was adopted from Vadjunina and Korchagina (1986). In soil samples as well as in size fractions of WSA, the soil organic carbon $\left(\mathrm{C}_{\text {org }}\right)$ and labile carbon $\left(\mathrm{C}_{\mathrm{L}}\right)$ contents were determined by Tyurin (Dziadowiec \& Gonet 1999) and by Loginow (Loginow et al. 1987), respectively. On the base of determined $\mathrm{C}_{\text {org }}$ and $\mathrm{C}_{\mathrm{L}}$ we calculated the following parameters of SOM: carbon lability $\left(\mathrm{L}_{\mathrm{C}}\right)$, lability index (LI), carbon pool index (CPI) and the carbon management index (CMI), as suggested Blair et al. (1995). In this research, the control (G) treatment was the reference and different soil management practices $(\mathrm{T}, \mathrm{T}+\mathrm{FYM}, \mathrm{G}+\mathrm{NPK} 3$ and $\mathrm{G}+\mathrm{NPK} 1)$ were used as treatments.

Analysis of variance for SOM parameters were performed using Statgraphics Centurion XV.I statistical software (Statpoint Technologies, Inc., USA). The difference between the treatments was examined by one-way analysis of variance (ANOVA) and the $L S D$ test $(P<0.05)$ was used for means comparison. Correlation analyses were used to assess the relationship between $\mathrm{L}_{\mathrm{C}}$, LI, CPI and CMI in the soil and the same parameters of SOM in individual size fractions of water-stable aggregates.

\section{RESULTS AND DISCUSSION}

\section{SOM in soil}

The values of carbon lability $\left(\mathrm{L}_{\mathrm{C}}\right)$ were not affected by soil management practices, however differences between treatments were observed. The content of $\mathrm{L}_{\mathrm{C}}$ increased on average in the following order: $\mathrm{G}+\mathrm{NPK} 1=\mathrm{T}<\mathrm{G}<\mathrm{T}+\mathrm{FYM}<\mathrm{G}+\mathrm{NPK} 3$. We also evaluated the effect of different soil management practices on changes in SOM parameters such as: LI, CPI and CMI, which are used for determination of smaller changes and changes over a short time period (Blair et al. 1995; Szombathová 1999; Vieira et al. 2007). Higher values of $\mathrm{L}_{\mathrm{C}}$ and LI indicated that SOM was rapidly degradable by micro-organisms, otherwise, lower values of LI indicated SOM had greater stability and resistance to microbial degradation. The highest LI values were found for the G+NPK3, T+FYM and G+NPK1 fertilised treatments and the lowest for the unfertilised, intensively tilled treatments (Table 2). Thus, higher doses of mineral fertilisers as well as organic amendment increased the amount of less stable forms of SOM, mainly by FYM addition, as well as by the promotion of root exudates excretion and the amount of grasses' residues, or through the decay of stable SOM due to high doses of NPK application $(\mathrm{G}+\mathrm{NPK} 3)$. Our findings are in agreement with Fröberg et al. (2013), Tong et al. (2014), who reported the impacts of mineral fertilisers and effect of manure on mineralization of SOM. Generally,

T

Analyses of variance of soil organic matter parameters

\begin{tabular}{|c|c|c|c|c|c|}
\hline \multirow{2}{*}{ Parameters } & \multicolumn{5}{|c|}{ Soil management } \\
\cline { 2 - 6 } & $\mathrm{G}$ & $\mathrm{T}$ & $\mathrm{T}+\mathrm{FYM}$ & $\mathrm{G}+\mathrm{NPK} 3$ & $\mathrm{G}+\mathrm{NPK} 1$ \\
\hline $\mathrm{L}_{\mathrm{C}}$ & $0.150^{\mathrm{a}}$ & $0.149^{\mathrm{a}}$ & $0.166^{\mathrm{a}}$ & $0.176^{\mathrm{a}}$ & $0.149^{\mathrm{a}}$ \\
LI & - & $0.831^{\mathrm{a}}$ & $1.104^{\mathrm{b}}$ & $1.184^{\mathrm{b}}$ & $1.073^{\mathrm{ab}}$ \\
CPI & - & $0.807^{\mathrm{a}}$ & $1.014^{\mathrm{b}}$ & $0.956^{\mathrm{b}}$ & $1.073^{\mathrm{b}}$ \\
CMI & - & $70.800^{\mathrm{a}}$ & $113.700^{\mathrm{b}}$ & $116.000^{\mathrm{b}}$ & $116.100^{\mathrm{b}}$ \\
\hline
\end{tabular}

G - control; T - tillage; T+FYM - tillage+farmyard manure; G+NPK3 - doses of NPK fertilisers in $3^{\text {rd }}$ intensity for vineyards; G+NPK1 - doses of NPK fertilisers in $1^{\text {st }}$ intensity for vineyards

$\mathrm{L}_{\mathrm{C}}$ - carbon lability; LI - lability index; CPI - carbon pool index; CMI - carbon management index

Different letters between columns $(\mathrm{a}, \mathrm{b})$ indicate that treatment means are significantly different at $P<0.05$ according to $L S D$ multiple-range test 
labile SOM is highly susceptible to mineralization. Our results non-significantly confirmed this fact by low value of CPI in G+NPK3 treatment. Conversely, intensive cultivation ( $\mathrm{T}$ treatment) was responsible for microbial decomposition of SOM, since aeration caused by cultivation stimulated decomposition and the subsequent mineralization of both labile and also later stable forms of SOM (Prasad et al. 2016), which resulted in an overall decrease of SOM quantity. Subsequently we found then that the $\mathrm{T}$ treatment contained the lowest stock of $\mathrm{C}_{\text {org }}(13.0 \mathrm{~g} / \mathrm{kg})$, and also, significantly, the lowest value of CPI (0.807). When we expressed LI from $\mathrm{C}_{\text {org }}\left(\mathrm{C}_{\mathrm{org}}\right.$ varied in different treatments: $\mathrm{G}=17.4 \mathrm{~g} / \mathrm{kg}, \mathrm{T}=13.0 \mathrm{~g} / \mathrm{kg}$,

T a b 1 e 3

Analysis of variance of organic and labile carbon contents in size fractions of water-stable aggregates

\begin{tabular}{|c|c|c|c|c|c|c|c|}
\hline \multirow{2}{*}{ Parameters } & \multirow{2}{*}{\multicolumn{2}{|c|}{$\begin{array}{l}\text { Size fraction of water-stable } \\
\text { aggregates in mm }\end{array}$}} & \multicolumn{5}{|c|}{ Treatments } \\
\hline & & & \multirow{2}{*}{$\begin{array}{c}\mathrm{G} \\
0.147^{\mathrm{a}} \\
\end{array}$} & \multirow{2}{*}{$\begin{array}{c}\mathrm{T} \\
0.197^{\mathrm{b}} \\
\end{array}$} & \multirow{2}{*}{$\begin{array}{c}\mathrm{T}+\mathrm{FYM} \\
0.176^{\mathrm{ab}} \\
\end{array}$} & \multirow{2}{*}{$\begin{array}{c}\text { G+NPK3 } \\
0.197^{\mathrm{b}} \\
\end{array}$} & \multirow{2}{*}{$\begin{array}{c}\text { G+NPK1 } \\
0.154^{\mathrm{ab}} \\
\end{array}$} \\
\hline \multirow{7}{*}{$\mathrm{Lc}$} & $\mathrm{WSA}_{\mathrm{mi}}$ & $<0.25$ & & & & & \\
\hline & \multirow{6}{*}{$\mathrm{WSA}_{\text {ma }}$} & $0.25-0.5$ & $0.143^{\mathrm{a}}$ & $0.183^{\mathrm{a}}$ & $0.177^{\mathrm{a}}$ & $0.164^{\mathrm{a}}$ & $0.164^{\mathrm{a}}$ \\
\hline & & $0.5-1.0$ & $0.140^{\mathrm{a}}$ & $0.159^{\mathrm{a}}$ & $0.151^{\mathrm{a}}$ & $0.176^{\mathrm{a}}$ & $0.173^{\mathrm{a}}$ \\
\hline & & $1.0-2.0$ & $0.130^{\mathrm{a}}$ & $0.192^{\mathrm{b}}$ & $0.159^{\mathrm{a}}$ & $0.149^{\mathrm{a}}$ & $0.130^{\mathrm{a}}$ \\
\hline & & $2.0-3.0$ & $0.132^{\mathrm{a}}$ & $0.166^{\mathrm{a}}$ & $0.150^{\mathrm{a}}$ & $0.147^{\mathrm{a}}$ & $0.146^{\mathrm{a}}$ \\
\hline & & $3.0-5.0$ & $0.139^{\mathrm{ab}}$ & $0.159^{\mathrm{ab}}$ & $0.152^{\mathrm{ab}}$ & $0.168^{\mathrm{b}}$ & $0.134^{\mathrm{a}}$ \\
\hline & & $>5.0$ & $0.128^{\mathrm{a}}$ & $0.169^{\mathrm{b}}$ & $0.162^{\mathrm{ab}}$ & $0.162^{\mathrm{ab}}$ & $0.133^{\mathrm{ab}}$ \\
\hline \multirow{7}{*}{ LI } & WSA $_{\mathrm{mi}}$ & $<0.25$ & - & $1.372^{\mathrm{a}}$ & $1.232^{\mathrm{a}}$ & $1.369^{\mathrm{a}}$ & $1.077^{\mathrm{a}}$ \\
\hline & \multirow{6}{*}{$\mathrm{WSA}_{\mathrm{ma}}$} & $0.25-0.5$ & - & $1.295^{\mathrm{a}}$ & $1.262^{\mathrm{a}}$ & $1.164^{\mathrm{a}}$ & $1.124^{\mathrm{a}}$ \\
\hline & & $0.5-1.0$ & - & $1.155^{\mathrm{a}}$ & $1.099^{\mathrm{a}}$ & $1.316^{\mathrm{a}}$ & $1.254^{\mathrm{a}}$ \\
\hline & & $1.0-2.0$ & - & $1.556^{\mathrm{b}}$ & $1.293^{\mathrm{ab}}$ & $1.178^{\mathrm{ab}}$ & $1.061^{\mathrm{a}}$ \\
\hline & & $2.0-3.0$ & - & $1.292^{\mathrm{a}}$ & $1.159^{\mathrm{a}}$ & $1.147^{\mathrm{a}}$ & $1.127^{\mathrm{a}}$ \\
\hline & & $3.0-5.0$ & - & $1.165^{\mathrm{ab}}$ & $1.110^{\mathrm{a}}$ & $1.274^{\mathrm{b}}$ & $0.989^{\mathrm{a}}$ \\
\hline & & $>5.0$ & - & $1.453^{\mathrm{a}}$ & $1.354^{\mathrm{a}}$ & $1.329^{\mathrm{a}}$ & $1.109^{\mathrm{a}}$ \\
\hline \multirow{7}{*}{ CPI } & $\mathrm{WSA}_{\mathrm{mi}}$ & $<0.25$ & - & $0.824^{\mathrm{a}}$ & $1.038^{\mathrm{b}}$ & $1.061^{\mathrm{b}}$ & $1.053^{\mathrm{b}}$ \\
\hline & \multirow{6}{*}{$\mathrm{WSA}_{\text {ma }}$} & $0.25-0.5$ & - & $0.915^{\mathrm{a}}$ & $1.165^{b}$ & $1.087^{\mathrm{ab}}$ & $1.098^{\mathrm{ab}}$ \\
\hline & & $0.5-1.0$ & - & $0.891^{\mathrm{a}}$ & $1.127^{b}$ & $1.017^{\mathrm{ab}}$ & $1.035^{\mathrm{ab}}$ \\
\hline & & $1.0-2.0$ & - & $0.955^{\mathrm{a}}$ & $1.173^{b}$ & $1.056^{\mathrm{ab}}$ & $1.062^{\mathrm{ab}}$ \\
\hline & & $2.0-3.0$ & - & $1.019^{\mathrm{a}}$ & $1.209^{b}$ & $1.167^{\mathrm{ab}}$ & $1.094^{\mathrm{ab}}$ \\
\hline & & $3.0-5.0$ & - & $1.098^{\mathrm{a}}$ & $1.334^{\mathrm{b}}$ & $1.191^{\mathrm{ab}}$ & $1.126^{\mathrm{a}}$ \\
\hline & & $>5.0$ & - & $1.087^{\mathrm{a}}$ & $1.439^{\mathrm{b}}$ & $1.134^{\mathrm{a}}$ & $1.030^{\mathrm{a}}$ \\
\hline \multirow{7}{*}{ CMI } & $\mathrm{WSA}_{\mathrm{mi}}$ & $<0.25$ & - & $117.2^{\mathrm{a}}$ & $131.9^{\mathrm{a}}$ & $143.4^{\mathrm{a}}$ & $112.8^{\mathrm{a}}$ \\
\hline & \multirow{6}{*}{$\mathrm{WSA}_{\mathrm{ma}}$} & $0.25-0.5$ & - & $119.7^{\mathrm{a}}$ & $146.6^{\mathrm{a}}$ & $126.3^{a}$ & $118.8^{\mathrm{a}}$ \\
\hline & & $0.5-1.0$ & - & $99.6^{\mathrm{a}}$ & $122.8^{\mathrm{a}}$ & $132.9^{\mathrm{a}}$ & $122.6^{\mathrm{a}}$ \\
\hline & & $1.0-2.0$ & - & $146.6^{\mathrm{a}}$ & $149.7^{\mathrm{a}}$ & $121.5^{\mathrm{a}}$ & $119.1^{\mathrm{a}}$ \\
\hline & & $2.0-3.0$ & - & $122.9^{\mathrm{a}}$ & $140.9^{\mathrm{a}}$ & $133.5^{\mathrm{a}}$ & $117.2^{\mathrm{a}}$ \\
\hline & & $3.0-5.0$ & - & $131.2^{\mathrm{a}}$ & $148.7^{\mathrm{a}}$ & $152.9^{\mathrm{a}}$ & $109.7^{\mathrm{a}}$ \\
\hline & & $>5.0$ & - & $171.9^{\mathrm{a}}$ & $197.5^{\mathrm{a}}$ & $151.5^{\mathrm{a}}$ & $117.0^{\mathrm{a}}$ \\
\hline
\end{tabular}

G - control; T - tillage; T+FYM - tillage+farmyard manure; G+NPK3 - doses of NPK fertilisers in $3^{\text {rd }}$ intensity for vineyards; G+NPK1 - doses of NPK fertilisers in $1^{\text {st }}$ intensity for vineyards

$\mathrm{L}_{\mathrm{C}}$ - carbon lability; LI - lability index; CPI - carbon pool index; CMI - carbon management index WSA $_{\mathrm{mi}}$ - water-stable micro-aggregates; WSA ma $_{\text {- water-stable macroaggregates }}$

Different letters between columns (a, b) indicate that treatment means are significantly different at $P<0.05$ according to $L S D$ multiple-range test 
$\mathrm{T}+\mathrm{FYM}=17.4 \mathrm{~g} / \mathrm{kg}, \mathrm{G}+\mathrm{NPK} 3=16.8 \mathrm{~g} / \mathrm{kg}$, in $\mathrm{G}+\mathrm{NPK} 1=18.4 \mathrm{~g} / \mathrm{kg}$ ), the most intense mineralization was observed in $\mathrm{G}+\mathrm{NPK} 3<\mathrm{T}+\mathrm{FYM}<\mathrm{T}<$ G+NPK1. Using Blair et al. (1995) and Conteh et al. (1999) recommendation of the use of CPI for determination of SOM content, we found the lower the CPI value is, the more soil degradation is intensified in terms of reduction of soil organic matter content. Soil CPI increased in the following order: $\mathrm{T}<\mathrm{G}+\mathrm{NPK} 3<\mathrm{T}+\mathrm{FYM}<\mathrm{G}+\mathrm{NPK} 1$. However, CPI was lower in $\mathrm{T}$ treatment by $18 \%, 26 \%$ and $33 \%$ than in G+NPK3, T+FYM and G+NPK1, respectively. We also calculated the values of CMI in the soil to examine the impact of soil management practices. Usually, lower values of CMI indicate more intensive changes in the content of organic matter due to soil management practices and more carbon released from the soil stock (Blair et al. 1995). In our study, when considering CMI indices, the most intense change was caused as a result of intensive cultivation. The highest accumulation of carbon as well as decomposable organic matter occurred in G+NPK1 (Table 2), while intensive tillage caused decreases in not only SOM content, but also the percentage of its labile forms, since these were quickly mineralized due to cultivation.

\section{SOM in water-stable aggregates}

Soil management practices in the vineyard had a statistically significant influence on $\mathrm{L}_{\mathrm{C}}$ in WSA. The largest values of $\mathrm{L}_{\mathrm{C}}$ in water-stable micro-aggregates $\left(\mathrm{WSA}_{\mathrm{mi}}\right)$ were found for the T, G+NPK3, then $\mathrm{T}+\mathrm{FYM}$ and $\mathrm{G}+\mathrm{NPK} 1$, whilst the smallest influence was seen for the G. The highest statistically significant difference of the $\mathrm{L}_{\mathrm{C}}$ in $\mathrm{WSA}_{\mathrm{mi}}$ was observed between the control and treatment with added fertilisers in $3^{\text {rd }}$ intensity for vineyards as well as tillage treatment. Carbon lability indices in greater sized (water-stable macro-aggregates) $\mathrm{WSA}_{\mathrm{ma}}(>3 \mathrm{~mm})$ copied this trend as was also seen in $\mathrm{L}_{\mathrm{C}}$ in $\mathrm{WSA}_{\mathrm{mi}}$ of the investigated soil treatments. In size fractions of WSA $_{\mathrm{ma}} 1-2 \mathrm{~mm}$ and $>5 \mathrm{~mm}$ the highest differences were observed between the control and tilled treatment. In all treatments, except G+NPK1, higher values of $\mathrm{L}_{\mathrm{C}}$ were determined in $\mathrm{WSA}_{\mathrm{mi}}$ than $\mathrm{WSA}_{\mathrm{ma}}$, which indicated higher proportions of labile carbon were in micro-aggregates. This means that micro-aggregates were more sensitive to the microbial de- composition than macro-aggregates. This is surprising because previous literature reports the opposite finding. Peth et al. (2008) and Kögel-Knabner et al. (2008) reported that SOM inside of micro-aggregates is more stabile due to better physical protection and physico-chemical protection. On average, the values of LI in WSA increased in the sequence G+NPK1 $(1.11 \pm 0.08)<\mathrm{T}+\mathrm{FYM}(1.22 \pm 0.10)<\mathrm{G}+\mathrm{NPK} 3$ $(1.30 \pm 0.11)<\mathrm{T}(1.33 \pm 0.15)$. The largest differences (statistically significant) were found between treatments $\mathrm{T}$ and G+NPK1 in fractions of $\mathrm{WSA}_{\text {ma }} 1-2$ $\mathrm{mm}$ and between the G+NPK3 and G+NPK1 in fractions of $\mathrm{WSA}_{\mathrm{ma}} 3-5 \mathrm{~mm}$. Lobe et al. (2001) reported that the largest content of total carbon $(60-90 \%)$ is found in small macro-aggregates and that micro-aggregates up to $40 \%$ may decrease carbon supply as a result of cultivation compared with meadows. Our results showed that the greatest vulnerability to degradation of organic matter was observed in the micro-aggregates (the greatest Lc and LI values) and also macro-aggregates (the greatest average $\mathrm{L}_{\mathrm{C}}$ and LI values) under intense cultivation of vine rows, which indirectly confirmed the findings of Lobe et al. (2001). The highest values of the CPI in WSA were detected as a result of farmyard manure application (Table 3). The results point to the fact that SOM is degraded not only in the soil but also in the WSA, especially due to intensive soil cultivation, which confirmed findings of several studies (Khorramdel et al. 2013; Abdollahi et al. 2014), and also as a result of the application of high doses of fertilisers to the soil (Yang et al. 2011). Results obtained in this study showed, that the greatest enrichment in C in WSA occurred in the T+FYM treatment, the depletion in $\mathrm{C}$ in $\mathrm{T}$ treatments, whereas in $\mathrm{G}+\mathrm{NPK} 1$ and $\mathrm{G}+\mathrm{NPK} 3$ treatments the values were almost the same. In $\mathrm{T}$ treatment, the average CPI in macro-aggregates was lower than 1 , what means a decreasing trend of organic carbon. In $\mathrm{T}$ treatment in addition to macro-aggregates, the CPI value was not lower than 1 also in micro-aggregates, which means that the microbial decomposition of organic matter occurred at the level of micro-aggregates, which may gradually result in the collapse of soil structure. Moreover, the lability of organic matter $\left(\mathrm{L}_{\mathrm{C}}\right)$ was the greatest just in $\mathrm{T}$ treatment (Table 3), indicating greater susceptibility of organic matter to decomposition. Although organic matter lability 
$\left(\mathrm{L}_{\mathrm{C}}\right)$ means the biodegradability of labile organic matter forms, the cultivation without organic and mineral fertilisers added, considerably accelerated the decrease of $\mathrm{C}_{\text {org }}$ - when in control treatment $\mathrm{C}_{\text {org }}$ was $17.4 \mathrm{~g} / \mathrm{kg}$, and in $\mathrm{T}$ treatment $13.0 \mathrm{~g} / \mathrm{kg}$. Generally, labile (active) forms of organic matter are precursors of the stable (passive, slow) forms of
SOM. When soil lacks labile organic matter, soil micro-organisms gradually use as a source of nutrients and energy more stable forms of SOM, and the result is a slow, gradual decrease of organic matter in the soil (Brady \& Weil 1999). Surprising finding was revealed that the largest changes in stocks of SOM in all soil management practices occurred in $\mathrm{WSA}_{\mathrm{mi}}$

$\mathrm{T}$ a $\mathrm{b} 1$ e 4

Correlation between SOM parameters in soil and water-stable aggregates

\begin{tabular}{|c|c|c|c|c|c|c|c|c|}
\hline \multirow{2}{*}{ Soil management } & \multirow{2}{*}{$\begin{array}{l}\text { SOM parameters } \\
\text { in soil }\end{array}$} & \multicolumn{7}{|c|}{ Size fractions of water-stable aggregates } \\
\hline & & $>5$ & $5-3$ & $3-2$ & $2-1$ & $1-0.5$ & $0.5-0.25$ & $<0.25$ \\
\hline \multirow{8}{*}{ Together } & & \multicolumn{7}{|c|}{$\mathrm{L}_{\mathrm{C}}$} \\
\hline & $\mathrm{L}_{\mathrm{C}}$ & n.s. & n.s. & n.s. & n.s. & n.s. & n.s. & n.s. \\
\hline & & \multicolumn{7}{|c|}{ LI } \\
\hline & LI & n.s. & n.s. & n.s. & n.s. & n.s. & n.s. & n.s. \\
\hline & & \multicolumn{7}{|c|}{ CPI } \\
\hline & CPI & $0.398^{+}$ & n.s. & $0.379^{+}$ & n.s. & $0.384^{+}$ & n.s. & $0.358^{+}$ \\
\hline & & \multicolumn{7}{|c|}{ CMI } \\
\hline & CMI & n.s. & n.s. & n.s. & n.s. & n.s. & n.s. & n.s. \\
\hline & \multirow{6}{*}{$\mathrm{L}_{\mathrm{C}}$} & \multicolumn{7}{|c|}{$\mathrm{L}_{\mathrm{C}}$} \\
\hline G & & n.s. & n.s. & n.s. & n.s. & n.s. & n.s. & n.s. \\
\hline $\mathrm{T}$ & & n.s. & n.s. & n.s. & n.s. & n.s. & n.s. & n.s. \\
\hline $\mathrm{T}+\mathrm{FYM}$ & & n.s. & n.s. & n.s. & n.s. & n.s. & n.s. & n.s. \\
\hline $\mathrm{G}+\mathrm{NPK} 3$ & & n.s. & n.s. & n.s. & n.s. & n.s. & n.s. & n.s. \\
\hline \multirow[t]{2}{*}{$\mathrm{G}+\mathrm{NPK} 1$} & & n.s. & n.s. & n.s. & n.s. & n.s. & n.s. & n.s. \\
\hline & \multirow{5}{*}{ LI } & \multicolumn{7}{|c|}{ LI } \\
\hline $\mathrm{T}$ & & n.s. & n.s. & n.s. & n.s. & n.s. & $0.739^{+}$ & n.s. \\
\hline T+FYM & & n.s. & n.s. & n.s. & n.s. & n.s. & n.s. & n.s. \\
\hline $\mathrm{G}+\mathrm{NPK} 3$ & & n.s. & n.s. & n.s. & n.s. & n.s. & n.s. & n.s. \\
\hline \multirow[t]{2}{*}{$\mathrm{G}+\mathrm{NPK} 1$} & & n.s. & n.s. & n.s. & n.s. & n.s. & n.s. & n.s. \\
\hline & \multirow{5}{*}{ CPI } & \multicolumn{7}{|c|}{ CPI } \\
\hline $\mathrm{T}$ & & $0.806^{+}$ & $0.750^{+}$ & n.s. & n.s. & n.s. & n.s. & n.s. \\
\hline T+FYM & & n.s. & $0.734^{+}$ & n.s. & n.s. & n.s. & n.s. & n.s. \\
\hline $\mathrm{G}+\mathrm{NPK} 3$ & & n.s. & n.s. & n.s. & n.s. & n.s. & n.s. & n.s. \\
\hline \multirow[t]{2}{*}{$\mathrm{G}+\mathrm{NPK} 1$} & & n.s. & n.s. & n.s. & n.s. & n.s. & n.s. & n.s. \\
\hline & & \multicolumn{7}{|c|}{ CMI } \\
\hline $\mathrm{T}$ & & n.s. & n.s. & n.s. & n.s. & $0.717^{+}$ & n.s. & n.s. \\
\hline $\mathrm{T}+\mathrm{FYM}$ & CMI & $0.723^{+}$ & n.s. & n.s. & n.s. & n.s. & n.s. & n.s. \\
\hline $\mathrm{G}+\mathrm{NPK} 3$ & & n.s. & n.s. & n.s. & n.s. & n.s. & n.s. & n.s. \\
\hline $\mathrm{G}+\mathrm{NPK} 1$ & & n.s. & n.s. & n.s. & n.s. & n.s. & n.s. & n.s. \\
\hline
\end{tabular}

${ }^{+} P \leq 0.05$; n.s. - non-significant

$\mathrm{G}$ - control; T - tillage; T+FYM - tillage+farmyard manure; G+NPK3 - doses of NPK fertilisers in $3^{\text {rd }}$ intensity for vineyards; G+NPK1 - doses of NPK fertilisers in $1^{\text {st }}$ intensity for vineyards

$\mathrm{L}_{\mathrm{C}}$ - carbon lability; LI - lability index; CPI - carbon pool index; CMI - carbon management index 
compared to $\mathrm{WSA}_{\mathrm{ma}}$. For example, Six et al. (2004) reported that macro-aggregates are less stable due to intensive soil cultivation and therefore break-up into micro-aggregates. Thus, significant changes in the carbon content, particularly in the largest fractions WSA $_{\text {ma }}$ recorded by Gale et al. (2000), are not consistent with our findings (Table 3 ). In the WSA we also calculated CMI indices depending on the soil management practices in vineyard. Overall, smaller CMI values, indicating minor changes in the content and quality of organic matter due to land management, were recorded more in $\mathrm{WSA}_{\mathrm{mi}}$ than WSA $_{\text {ma }}$ (except G+NPK3). The lowest value of CMI in $\mathrm{WSA}_{\mathrm{mi}}$ was determined in G+NPK1 and T treatments (Table 3). One-way ANOVA analysis did not confirm significant differences between treatments in contents of $\mathrm{WSA}_{\mathrm{ma}}$. The largest accumulation of $\mathrm{SOM}$ was detected in the size fraction of $\mathrm{WSA}_{\mathrm{ma}}>5$ $\mathrm{mm}$ due to application of farmyard manure and application of fertilisers in $3^{\text {rd }}$ intensity for vineyards, but also due to intensive cultivation of vine rows. In G+NPK1, the highest accumulation of SOM was observed in size fraction of $\mathrm{WSA}_{\mathrm{ma}} 5-3 \mathrm{~mm}$.

Correlations between SOM parameters in soil and in WSA

Correlation coefficients between SOM parameters in soil and in WSA are shown in Table 4. When the $L_{C}$ and LI values were assessed together regardless of soil management practices, no correlation was recorded. However, the value of LI in soil positively correlated with LI in $\mathrm{WSA}_{\text {ma }}$ $0.5-0.25 \mathrm{~mm}$, but only under $\mathrm{T}$ treatment. This means that intensive cultivation between vine rows can increase the lability of carbon in smaller macro-aggregates. Statistically significant positive correlations were observed between CPI in soil and CPI in WSA (together), and this effect was stronger in size fractions of $5-3 \mathrm{~mm}, 2-1 \mathrm{~mm}$ and $0.5-0.25 \mathrm{~mm}$. As the CPI values were assessed with relation to soil management practices, we detected a positive significant correlation between CPI in soil and CPI in $\mathrm{WSA}_{\text {ma }}$ in size fractions of $>5 \mathrm{~mm}$ and $5-3 \mathrm{~mm}$ under intensive cultivated rows of vine, and in fractions of $5-3 \mathrm{~mm}$ in treatments with ploughed farmyard manure (Table 4). Statistically significant positive correlation was observed between CMI in soil and CMI in $\mathrm{WSA}_{\text {ma }}$
$1-0.5 \mathrm{~mm}$, if the CMI values were assessed together, regardless of soil management practices in the vineyard. Evaluating CMI values in relation to soil management practices, we only detected positive significant correlation between CMI in soil and CMI in $\mathrm{WSA}_{\mathrm{ma}}$ in size fractions of $1-0.5 \mathrm{~mm}$ under $\mathrm{T}$ treatment and $>5 \mathrm{~mm}$ in T+FYM treatment (Table 4).

\section{CONCLUSIONS}

This study indicates that the highest accumulation of carbon, as well decomposable organic matter in soil, occurred in treatments with the application of fertilisers in $1^{\text {-st }}$ intensity for vineyards compared other fertilised treatment, while intensive tillage caused the decrease not only of total SOM content, but also its labile forms, which were quickly mineralized due to cultivation. Similarly, the greatest vulnerability of organic matter to degradation was observed in the WSA under T treatment, however, the highest accumulation of SOM in WSA were detected as a result of farmyard manure application. Results further showed that between CPI in soil and WSA there were significant relationships if all soil management practices were assessed together. When soil management practices in a vineyard have been assessed separately, there were clear relationships between CPI in soil and higher size fraction of water-stable macro-aggregates.

Acknowledgements. We thank Matthew Evans (Brackley Northants, England) for help with improving the editorial presentation of this paper. Project supported by the Scientific Grant Agency of the Ministry of Education, Science, Research and Sport of the Slovak Republic and the Slovak Academy of Sciences (No. 1/0604/16).

\section{REFERENCES}

ABDOLLAHI, L. - SCHJØNNING, P. - ELMHOLT, S. MUNKHOLM, L.J. 2014. The effects of organic matter application and intensive tillage and traffic on soil structure formation and stability. In Soil \& Tillage Research, vol. 136, pp. 28-37. DOI: 10.1016/S01671987(97)00038-X

BELAY-TEDLA, A. - ZHOU, X. - SU, B. - WAN, S. - LUO, Y. 2009. Labile, recalcitrant, and microbial carbon 
and nitrogen pools of a tallgrass prairie soil in the US Great Plains subjected to experimental warming and clipping. In Soil Biology \& Biochemistry, vol. 41, no. 1, pp. 110-116. DOI: 10.1016/j.soilbio.2008.10.003

BENBI, D.K. - BRAR, K. - TOOR, A.S. - SHARMA, S. 2015. Sensitivity of labile soil organic carbon pools to long-term fertilizer, straw and manure management in rice-wheat system. In Pedosphere, vol. 25, no. 4, pp. 534-545. DOI: 10.1016/S1002-0160(15)30034-5

BENBI, D.K. - BRAR, K. - TOOR, A.S. - SINGH, P. - SINGH, H. 2012. Soil carbon pools under poplar-based agroforestry, rice-wheat, and maize-wheat cropping systems in semi-arid India. In Nutrient Cycling in Agroecosystems, vol. 92, no. 1, pp. 107118. DOI: $10.1007 / \mathrm{s} 10705-011-9475-8$

BLAIR, G.J. - LEFROY, R.D.B. - LISLE, L. 1995. Soil carbon fractions based on their degree of oxidation, and the development of a carbon management index for agricultural system. In Australian Journal of Agricultural Research, vol. 46, pp. 1459-1466.

BRADY, N.G. - WEIL, R.R. 1999. The nature and properties of soils. 12. ed. New Jersey: Prentice - Hall, Inc. Simons \& Schuster A Viacon Comp., $881 \mathrm{p}$.

CONTEH, A. - BLAIR, G.J. - LEFROY, R.D.B. WHITBREAD, A. 1999. Labile organic carbon determined by permangante oxidation and its relationships to other measurements of soil organic carbon. In Humic Substances in the Environment, vol. 1, pp. $3-15$.

DZIADOWIEC, H. - GONET, S.S. 1999. Przewodnik metodyczny do badań materii organicznej gleb [Methodical guide-book for soil organic matter studies]. Prace Komisji Naukowych Polskiego Towarzystwa Gleboznawczego, N. 120, Komisja chemii gleb, Zespół Materii Organicznej Gleb, N II/16, $65 \mathrm{p}$.

FECENKO, J. - LOŽEK, O. 2000. Výživa a hnojenie pol'ných plodín [Nutrition and fertilization of field crops]. Nitra: SPU, pp. 452.

FRÖBERG, M. - GRIP, H. - TIPPING, E. - SVENSSON, M. - STRÖMGREN, M. - KLEJA, D.B. 2013. Longterm effects of experimental fertilization and soil warming on dissolved organic matter leaching from a spruce forest in Northern Sweden. In Geoderma vol. 200-201, pp. 172-179. DOI: 10.1016/j.geoderma.2013.02.002

GALE, W.J. - CAMBARDELlA, C.A. - BAILEY, T.B. 2000. Surface residue- and root-derived carbon in stable and unstable aggregates. In Soil Science Society of American Journal, vol. 64, no. 1, pp. 196-201. DOI: $10.2136 /$ sssaj2000.641196x

IUSS Working Group WRB. 2006. World reference base for soil resources 2006. 2nd edition. World Soil Resources Reports No. 103. Rome: FAO, pp. 145.

KHORRAMDEL, S. - KOOCHEKI, A. - MAHALLATI, M.N. - KHORASANI, R. - GHORBANI, R. 2013. Evaluation of carbon sequestration potential in corn fields with different management systems. In Soil \& Tillage Research, vo1. 133, pp. 25-31. DOI: 10.1016/ S0167-1987(97)00038-X
KÖGEL-KNABNER, I. - EKSCHMITT, K. - FLESSA, H. - GUGGENBERGER, G. - MATZNER, E. MARSCHNER, B. - VON LÜTZOW, M. 2008. An intergrative approach of organic matter stabilization in temperate soils: Linking chemistry, physics and biology. In Journal of Plant Nutrition and Soil Science, vol. 171, no. 1, pp. 5-13. DOI: 10.1002/ jpln.200700215

KOLÁř, L. - VANĚK, V. - KUŽEL, S. - PETERKA, J. - BOROVÁ-BATT, J. - PEZLAROVÁ, J. 2011. Relationships between quality and quantity of soil labile fraction of the soil carbon in Cambisols after liming during a 5-year period. In Plant Soil and Environment, vol. 57, no. 5, pp. 193-200.

LOBE, I. - AMELUNG, W. - DU PREEZ, C.C. 2001. Losses of carbon and nitrogen with prolonged arable cropping from sandy soils of the South African Highveld. In European Journal of Soil Science, vol. 52, no. 1, pp. 93-101. DOI: 10.1046/j.13652389.2001.t01-1-00362.x

LUGATO, E. - BERTI, A. 2008. Potential carbon sequestration in a cultivated soil under different climate change scenarios: a modelling approach for evaluating promising management practices in north-east Italy. In Agriculture, Ecosystems \& Environment, vol. 128 , no. $1-2$, pp. 97-103. DOI: $10.1016 / \mathrm{j}$. agee.2008.05.005

ŁOGINOW, W. - WISNIEWSKI, W. - GONET, S.S. CIESCINSKA, B. 1987. Fractionation of organic carbon based on susceptibility to oxidation. In Polish Journal of Soil Science, vol. 20, pp. 47-52.

McLAUCHLAN, K.K. - HOBBIE, S.E. 2004. Comparison of labile soil organic matter fractionation techniques. In Soil Science Society of American Journal, vol. 68, no. 5, pp. 1616-1625. DOI: 10.2136/sssaj2004.1616

PETH, S. - HORN, R. - BECKMANN, F. - DONATH, T. - FISCHER, J. - SMUCKER, A.J.M. 2008. Threedimensional quantification of intra-aggregate porespace features using synchrotron-radiation-based microtomography. In Soil Science Society of American Journal, vol. 72, pp. 897-907. DOI: 10.2136/sssaj2007.0130

PRASAD, J.V.N.S. - SRINIVASA RAO, CH. - SRINIVAS, K. - NAGA JYOTHI, CH. - VENKATESWARLU, B. - RAMACHANDRAPPA, B.K. - DHANAPAL, G.N. - RAVICHANDRA, K. - MISHRA, P.K. 2016. Effect of ten years of reduced tillage and recycling of organic matter on crop yields, soil organic carbon and its fractions in Alfisols of semi arid tropics of southern India. In Soil \& Tillage Research, vol. 156, pp. 131-139. DOI: 10.1016/j.still.2015.10.013

REEVES, D.W. 1997. The role of soil organic matter in maintaining soil quality in continuous cropping system. In Soil \& Tillage Research, vol. 43, no. 1-2, pp. 131-167. DOI: 10.1016/S0167-1987(97)00038-X

SCHEPASCHENKO, D.G. - MUKHORTOVA, L.V. SHVIDENKO, A.Z. - VEDROVA, E.F. 2013. The pool of organic carbon in the soils of Russia. In Eurasian Soil Science, vol. 46, no. 2, pp. 107-116. DOI: $10.1134 / \mathrm{S} 1064229313020129$ 
SEMENOV, V.M. - TULINA, A.S. - SEMENOVA, N.A. IVANNIKOVA, L.A. 2013. Humification and nonhumification pathways of the organic matter stabilization in soil: A Review. In Eurasian Soil Science, vol. 46, pp. 355-368. DOI: 10.1134/S106422931304011X

SHANG, W. - WU, X. - ZHAO, L. - YUE, G. - ZHAO, Y. - QIAO, Y. - LI, Y. 2016. Seasonal variations in labile soil organic matter fractions in permafrost soils with different vegetation types in the central QinghaiTibet Plateau. In Catena, vol. 137, pp. 670-678. DOI: 10.1016/j.catena.2015.07.012

ŠIMANSKÝ, V. - POLLÁKOVÁ, N. 2014. Soil organic matter and sorption capacity under different soil management practices in a productive vineyard. In Archives of Agronomy and Soil Science, vol. 60, no. 8, pp. 1145-1154. DOI: 10.1080/03650340.2013.865837

SIX, J. - BOSSUYT, H. - DEGRYZE, S. - DENEF, K. 2004. A history of research on the link between (micro)aggregates, soil biota, and soil organic matter dynamics. In Soil and Tillage Research, vol. 79, pp. 7-31. DOI: 10.1016/j.still.2004.03.008

STEVENSON, F.J. 1982. Humus chemistry, genesis, composition, reactions. 3. ed. New York: Wiley \& Sons, $443 \mathrm{p}$.

SZOMBATHOVÁ, N. 1999. The comparison of soil carbon susceptibility to oxidation by $\mathrm{KMnO}_{4}$ solutions in different farming systems. In Humic substances in the environment, vol. 1, p. 35-39.

SZOMBATHOVÁ, N. 2010. Chemické a fyzikálno-chemické vlastnosti humusových látok pôd ako ukazovatel' antropogénnych zmien $\mathrm{v}$ ekosystémoch (lokality Báb a Dolná Malanta) [Chemical and physico-chemical properties of soil humic substances as an indicator of anthropogenic changes in ecosystems (Báb and Dolná Malanta localities)]. Nitra: SPU, 96 p.

TONG, X. - XU, M. - WANG, X. - BHATTACHARYYA, R. - ZHANG, W. - CONG, R. 2014. Long-term fertilization effects on organic carbon fractions in a red soil of China. In Catena, vol. 113, pp. 251-259. DOI: 10.1016/j.catena.2013.08.005

VADJUNINA, A.F. - KORCHAGINA, Z.A. 1986. Methods of study of soil physical properties. Moscow : Agropromizdat, $415 \mathrm{p}$.

VIEIRA, F.C.B. - BAYER, C. - ZANATTA, J.A. DIECKOW, J. - MIELNICZUK, J. - HE, Z.L. 2007. Carbon management index based on physical fractionation of soil organic matter in an Acrisol under long-term no-till cropping systems. In Soil \& Tillage Research, vol. 96, no. 1-2, pp. 195-204. DOI: 10.1016/j.still.2007.06.007

YANG, X.Y. - LI, P.R. - ZHANG, S.L. - SUN, B.H. CHEN, X.P. 2011. Long-term-fertilization effects on soil organic carbon, physical properties, and wheat yield of a loess soil. In Journal of Plant Nutrition and Soil Science, vol. 174, pp. 775-784. DOI: 10.1002/ jpln.201000134

Received: February 16, 2016 